\title{
Pathogenicity of Metarhizium anisopliae and Beauveria bassiana fungi to Tetranychus Iudeni (Acari: Tetranychidae)
}

\section{Patogenicidade de fungos Metarhizium anisopliae $e$ Beauveria bassiana ao Tetranychus ludeni (Acari: Tetranychidae)}

\author{
Samuel Luan Pereira' ${ }^{1}$, Tatiane Carla Reis ${ }^{1}$ (D), Ivani Teixeira de Oliveira' ${ }^{1}$, \\ Evander Alves Ferreira ${ }^{2 *}$ (D), Bárbara Monteiro de Castro e Castro ${ }^{3}$ (D), Marcus Alvarenga Soares ${ }^{1}$ (D), \\ Victor Hugo Vidal Ribeiro'
}

\begin{abstract}
The use of acaricides is the main control method for Tetranychus ludeni (Acari: Tetranychidae) in horticultural crops. This mite has been recorded causing damage to sweet potato (Ipomoea batatas L.). The use of pathogenic fungi is an alternative to chemical control. The objective was to evaluate the pathogenicity of the fungi Metarhizium anisopliae (Meetch) Sorok, and Beauveria bassiana (Bals.) Vuill. to phytophagous mite T. ludeni in sweet potato plants. Conidial suspensions of $M$. anisopliae and $B$. bassiana, at concentrations of $10^{6}$ and $10^{7} \mathrm{con} \cdot \mathrm{mL}^{-1}$ were applied to sweet potato leaves. After 24 hours, five females of T. ludeni newly emerged were released on the leaves. The bioassay was arranged in a completely randomized design with factorial arrangement $2 \times$ 2 (two species of fungi and two concentrations) plus the control (distilled water), with 10 repetitions per treatment. The evaluation consisted of observing of three biological parameters of the mite: mortality, oviposition, and repellency, after 24, 48, 72, and 96 hours of contact with the fungi. The isolates of $M$. anisopliae cause high mortality rates of T. ludeni in laboratory. Beauveria bassiana has the potential to suppress future generations of mite, reducing its oviposition rate. Repellency behavior was not observed.
\end{abstract}

KEYWORDS: Beauveria bassiana; Metarhizium anisopliae; biological control; red mite.
RESUMO: O uso de acaricidas é o principal método de controle de Tetranychus ludeni (Acari: Tetranychidae) em cultivos hortícolas. Esse ácaro foi registrado causando danos em batata-doce (Ipomoea batatas (L.). A utilização de fungos patogênicos é uma alternativa ao controle químico. O objetivo foi avaliar a patogenicidade dos fungos Metarhizium anisopliae (Meetch) Sorok. e Beauveria bassiana (Bals.) Vuill. ao ácaro fitófago T. ludeni em batata-doce. Suspensões conidiais de $M$. anisopliae e $B$. bassiana, nas concentraçóes de $10^{6}$ e $10^{7} \mathrm{con} \cdot \mathrm{mL}^{-1}$, foram aplicadas sobre folhas de batata-doce. Após 24 horas, cinco fêmeas recém-emergidas foram liberadas sobre as folhas. O bioensaio foi inteiramente randomizado, com arranjo fatorial $2 \times 2$ (duas espécies de fungos e duas concentraçóes) e controle (água destilada), com 10 replicaçóes por tratamento. A avaliação consistiu na observação de três parâmetros biológicos do ácaro: mortalidade, oviposição e repelência, após 24, 48, 72 e 96 horas de contato com os fungos. Os isolados de $M$. anisopliae causam altas taxas de mortalidade de T. ludeni em laboratório. Beauveria bassiana tem potencial para suprimir futuras geraçóes do ácaro, reduzindo a taxa de oviposição. Comportamento de repelência nos ácaros não foi observado.

PALAVRAS-CHAVE: Beauveria bassiana; Metarhizium anisopliae; controle biológico; ácaro vermelho. 


\section{INTRODUCTION}

Ipomoea batatas (L.) Lam. (Convolvulaceae), the sweet potato, is the seventh most important vegetable in the world (SONG et al., 2014), standing out for its easy cultivation, rusticity, adaptation to different soil types and climate, drought tolerance, and low production cost (ANDRADE JÚNIOR et al., 2012). Grown in practically all Brazilian regions, I. batatas is an excellent energy source due to its high carbohydrate and sugar content (MASSAROTO et al., 2013). It is used in human and animal food and has potential, as a raw material, to produce biofuels (ethanol) (SANTOS et al., 2010).

Pests may limit the production of $I$. batatas, reducing the quality and volume of roots (AZEVEDO et al., 2015). Phytophagous mites, such as Tetranychus desertorum (Banks), Tetranychus ludeni (Zacher), and Tetranychus urticae (Koch) (Acari: Tetranychidae) were reported for causing damage to I. batatas (MINEIRO et al., 2007; SOARES et al., 2012). Phytophagous mites cause damage when feeding on leaves, reducing their photosynthetic area (SOARES et al., 2012). Tetranychus ludeni, an arthropod polyphagous, occurs in the field most of the year. Leaves attacked by this mite initially have small yellowish spots, followed by necrotic spots, that take over the entire leaf, which later dries and falls (KAIMAL; RAMANI, 2011).

The use of acaricides is the main method of T. ludeni control in horticultural crops (KOUSIK et al., 2007), but it was already shown to be unfeasible, due to the high cost of pesticides in Brazil and the absence of selective and registered acaricides for the crop in the country (MAPA, 2016). The adverse effects of pesticides and restrictions on their application have encouraged the exploration of environmentally friendly pest control tactics (KHEDERI et al., 2014).

Pathogenic fungi, such as Beauveria bassiana (Balsamo) Vuillemin and Metarbizium anisopliae (Meetchnikoff) Sorokin, can regulate arthropod pest populations by penetrating their cuticles and destroying their tissues (KURTTI; KEYHANI, 2008; ROSSONI et al., 2014; COSTA et al., 2015). The ease of dispersal of these microorganisms in the field is one of the factors that fuel studies to investigate their use as biological control agents (MEYLING et al., 2009; COSTA et al., 2015).

The objective of the present study was to evaluate the pathogenicity of the fungi $M$. anisopliae and B. bassiana to the phytophagous mite T. ludeni in sweet potato, under laboratory conditions.

\section{MATERIAL AND METHODS}

The experiment was carried out at the Insect Biological Control laboratory of Universidade Federal dos Vales do Jequitinhonha e Mucuri (UFVJM) in Diamantina - MG. Tetranychus ludeni was reared in conditions of humidity $(65 \pm 10 \%)$, temperature $\left(25 \pm 1^{\circ} \mathrm{C}\right)$, and photoperiod of 12 hours. Two hundred and fifty females of T. ludeni were used for the bioassay, and fifty females per treatment.

Ten leaf circles of $2 \mathrm{~cm}$ in diameter, per treatment, were cut from the sweet potato genotype BD 29, derived from the UFVJM germplasm bank. The leaf circles were surrounded with cotton, moistened with distilled water, and placed over nylon foam and in a tray. The foam was kept moist with the addition of distilled water (SOARES et al., 2012; ULLAH; LIM, 2015).

Suspensions containing fungal conidia were obtained from the commercial products Metarril WP E9 and Boveril ${ }^{\circ}$ WP PL 63 (Koppert Biological Systems). Conidia was suspended in an aqueous solution containing $0.01 \%$ Tween $^{\circ} 80$ (ALMEIDA et al., 2006; ULLAH; LIM, 2015) at concentrations of $10^{6}$ and $10^{7}$ con.mL $\mathrm{mL}^{-1}$ for each isolate. Leaf circles were sprayed $100 \mu \mathrm{L}$ of the suspensions of the isolates of $M$. anisopliae and B. bassiana, homogeneously.

After 24 hours, leaf circles were dry and conidia adhered to the plant's surface, and five freshly emerged T. ludeni females were released in each circle and kept at $25 \pm 2^{\circ} \mathrm{C}, 70^{\circ} \mathrm{C} \pm 10 \%$ relative humidity and 12 hour photophase. The bioassay was arranged in a completely randomized design with a $2 \times 2$ factorial arrangement (two fungal species and two conidia concentrations), and the control (distilled water) with 10 replications per treatment.

Tetranychus ludeni females in the leaf circles were observed under a stereomicroscope after 24, 48, 72, and 96 hours of contact with the fungi. Biological parameters evaluated were mortality, oviposition, and repellency. The mortality data of T. ludeni females were evaluated using the quadratic polynomial regression model, with significant curves with the Student's $t$ test. The oviposition and repellency rates of the mites were compared using the Tukey test at $5 \%$ significance with free software $\mathrm{R}^{\circledR}$.

\section{RESULTS AND DISCUSSION}

In the evaluation of the mortality percentage of $T$. ludeni (in sweet potato leaf samples), after a period of 96 hours after treatment with two suspensions containing $M$. anisopliae conidia plus one control, it was found that the higher conidia concentration in the suspension $\left(10^{7}\right.$ con. $\left.\mathrm{mL}^{-1}\right)$ of $M$. anisopliae caused a higher mortality percentage of T. ludeni females in relation to the treatment where fungus concentration was $10^{6}$ con. $\mathrm{mL}^{-1}$ and the control treatment. In the last evaluation period (96 hours) was observed that the mortality percentage was $80 \%$ in the highest concentration. These values were 52 and $40 \%$ in the concentration of 106 con. $\mathrm{mL}^{-1}$ and in the control treatment, respectively (Fig. 1A). The mites treated with suspension containing the fungus $B$. bassiana showed 
an increase in mortality in all treatments compared to the control, and this variable showed similar mean values during the evaluation periods in the two concentrations tested. The maximum mortality of $T$. ludeni females observed after 96 hours was 30\% (Fig. 1B).

According to TAMAI et al. (2002), the fungus Metarhizium anisopliae presents higher pathogenicity to T. urticae than $B$. bassiana. In reports by BUGEME et al. (2015), with $M$. anisopliae (isolated ICIPE78), the authors concluded that suspensions containing conidia of this fungus constitute an alternative to the use of acaricides to reduce T. urticae populations in common bean. The same authors also point out that $M$. anisopliae presents control similar to that obtained with acaricide abamectin in greenhouse and field.

SANJAYA et al. (2015) observed that different isolates of B. bassiana, M. anisopliae, and Paecilomyces lilacinus, at concentrations of $10^{5}, 10^{6}, 10^{7}$ and $10^{8}$ con.mL ${ }^{-1}$, control Tetranychus kanzi Kishida (Acari: Tetranychidae) mite.

ULLAH; LIM (2015) showed an effect of different concentrations of $M$. anisopliae and B. bassianafunguson T. urticae, reporting mortality rates above $50 \%$ in all concentrations. The authors also found that the highest mortality rate, $98.31 \%$, was reached by the $M$. anisopliae isolate, and applications of B. bassiana $\left(10^{8} \mathrm{con} \cdot \mathrm{mL}^{-1}\right)$ reduced T. urticae damage by $94 \%$ in common bean.

In the paper by BARRETO et al. (2004), different concentrations of B. bassiana control up to $91 \%$ of the population of the green mite Mononychellus tanajoa (Bondar) (Acari: Tetranychidae), whereas isolates of $M$. anisopliae $\left(10^{8} \mathrm{con}\right.$. $\mathrm{mL}^{-1}$ ) caused $45 \%$ of mortality.

The high mortality values obtained with $M$. anisopliae isolates on the fourth day indicate a fast action of the pathogen on T. ludeni (Fig. 1A).

Mites in crops with high economic damage, such as ornamental crops and horticulture, require a rapid control.
Isolates must be capable of causing high mortality, requiring less frequent spraying and reducing costs (TAMAI et al., 2002). The pathogenicity of acaropathogenic fungi can vary among mites, crops, and even cultivars (RIBEIRO et al., 2009; MORO et al., 2011).

In the present paper, the fungus $M$. anisopliae was effective to control T. ludeni. The B. bassiana fungus had a lower effectiveness in controlling the mite.

When evaluating the oviposition rate of $T$. ludeni females after treatment with different concentrations of $M$. anisopliae fungus conidia, the highest concentration of fungus conidia $\left(10^{7}\right.$ con. $\left.\mathrm{mL}^{-1}\right)$ provided the greatest reduction in this variable, differing from the other treatments (Fig. 2A).

The two B. bassiana conidia concentrations used to control T. ludeni were efficient in reducing oviposition of insect females, differing from the results found in the control treatment (Fig. 2B). Stressing factors, such as pathogens or toxic substances, may reduce the oviposition of phytophagous mites (SILVA et al., 2013), an effect considered important in IPM, because it reduces future generations of phytophagous. Sublethal effects of pathogenic fungi on target pests should be considered. Bemisia tabaci (Gennadius) (Hemiptera: Aleyrodidae) firstgeneration nymphs of adult descent treated with $B$. bassiana isolates are less successful in the molting process, and are not able to completely separate from the exuviae (TORRADOLEÓN et al., 2006; WANG et al., 2014).

The effect of fungi on pest fecundity confirms their pathogenic potential as biological control agents and can be demonstrated by the difference in fecundity between infected and uninfected pests (WEKESA et al., 2006; SHI; FENG, 2009). SEYED-TALEBI et al. (2012) found that T. urticae longevity, oviposition period, and fecundity were lower in individuals treated with B. bassiana. Moreover, B.bassiana (GZGY-1-3) has toxic and sublethal effects on Frankliniella occidentalis Pergande (Thysanoptera: Thripidae),
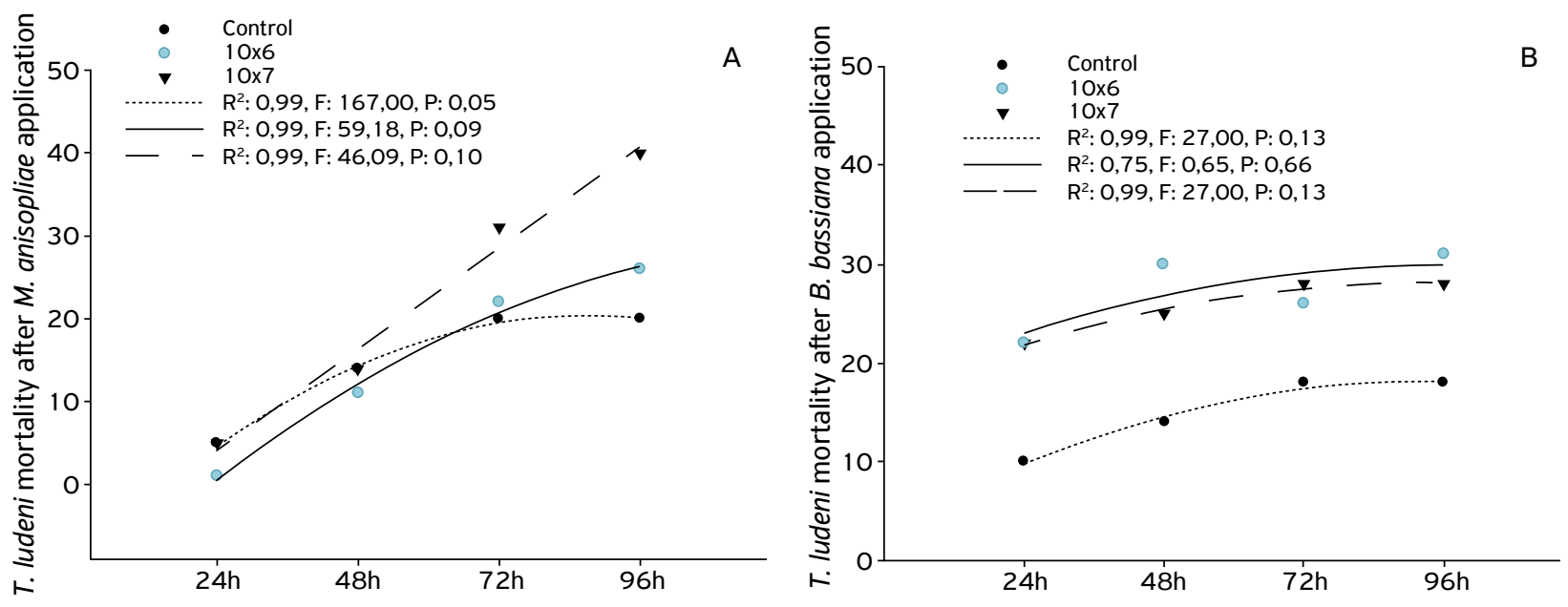

Figure 1. Mortality percentage of Tetranychus ludeni females after applying different concentrations of (A) Metarhizium anisopliae; and (B) Beauveria bassiana. 
reducing reproductive success (ZHANG et al., 2015). Thrips that survive the action of the pathogen fungus have less reproductive success and aptitude than their offspring, which slows down population growth rates (LI et al., 2013). Sublethal effects caused by fungal infections were also observed in Tetranychus evansi Baker \& Pritchard 1960 (Acari: Tetranychidae) (WEKESA et al., 2006) and T. urticae (ROSAS-ACEVEDO et al., 2003). Infections caused by B. bassiana and $M$. anisopliae caused mortality in T. ludeni females and reduced their fecundity. In the present study, there was a higher mortality of $T$. ludeni females when they were treated with conidia suspension containing $M$. anisopliae in relation to B. bassiana (Figs. $1 \mathrm{~A}$ and $1 \mathrm{~B})$. However, treatment with $B$. bassiana provided lower oviposition rate of $T$. ludeni females than $M$. anisopliae (Figs. 2A and 2B), indicating differentiated efficiency of the two acaropathogenic fungi. $M$. anisopliae most clearly affected the pest mortality rate; and B. bassiana interfered in the reproduction of $T$. ludeni females.

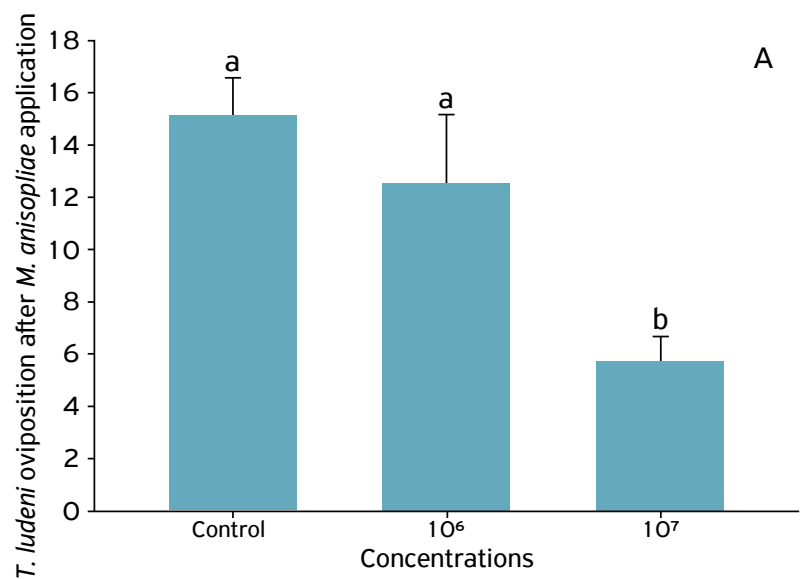

The higher concentration of $M$. anisopliae conidia $\left(10^{7}\right.$ con. $\mathrm{mL}^{-1}$ ) promoted higher repellency rate of $T$. ludeni females, without differing from other treatments (Fig. 3A). The females of $T$. ludeni treated with the fungus $B$. bassiana showed no difference in the repellency rate between the different concentrations and the control (Fig. 3B).

Mites were not found adhered to the damp cotton layer, surrounding leaf circles, in any of the $M$. anisopliae and $B$. bassiana conidia concentrations, thus not demonstrating an escape behavior. Repellent behavior was not observed after 96 hours of contact with acaropathogenic fungi (Figs. 3A and 3B). In a study by BARRETO et al. (2004), isolates of B. bassiana at a concentration of $10^{8} \mathrm{con} \cdot \mathrm{mL}^{-1}$ caused repellency in M. tanajoa after 12 hours of evaluation. However, the escape percentage did not exceed $8 \%$.

For greater efficiency in sweet potato Integrated Pest Management (IPM) programs, the use of the pathogens $B$. bassiana and M. anisopliaein mixture and with other natural control agents, such as predatory mites, should be investigated (CASTRO et al., 2014).

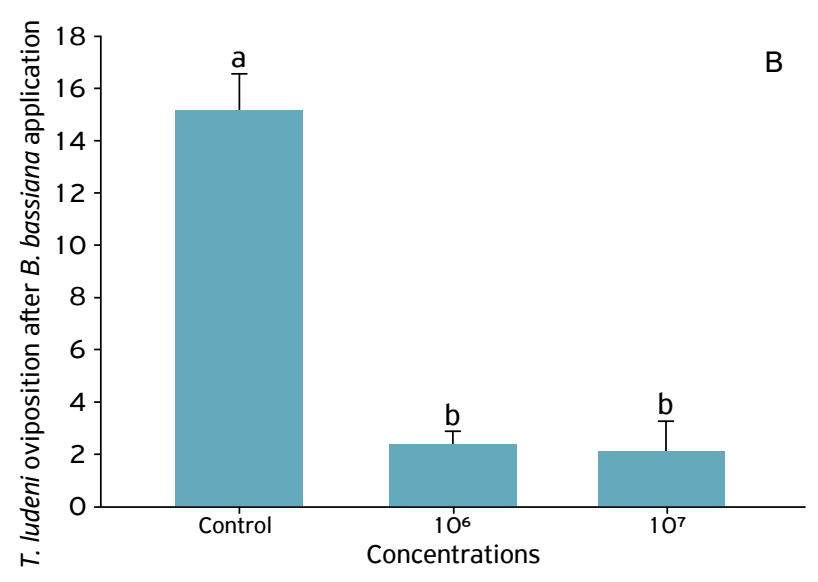

Figure 2. Tetranychus ludeni oviposition after applying different concentrations of (A) Metarhizium anisopliae; and (B) Beauveria bassiana. Means were compared with the Tukey test, $\mathrm{p} \geq 0.05$.
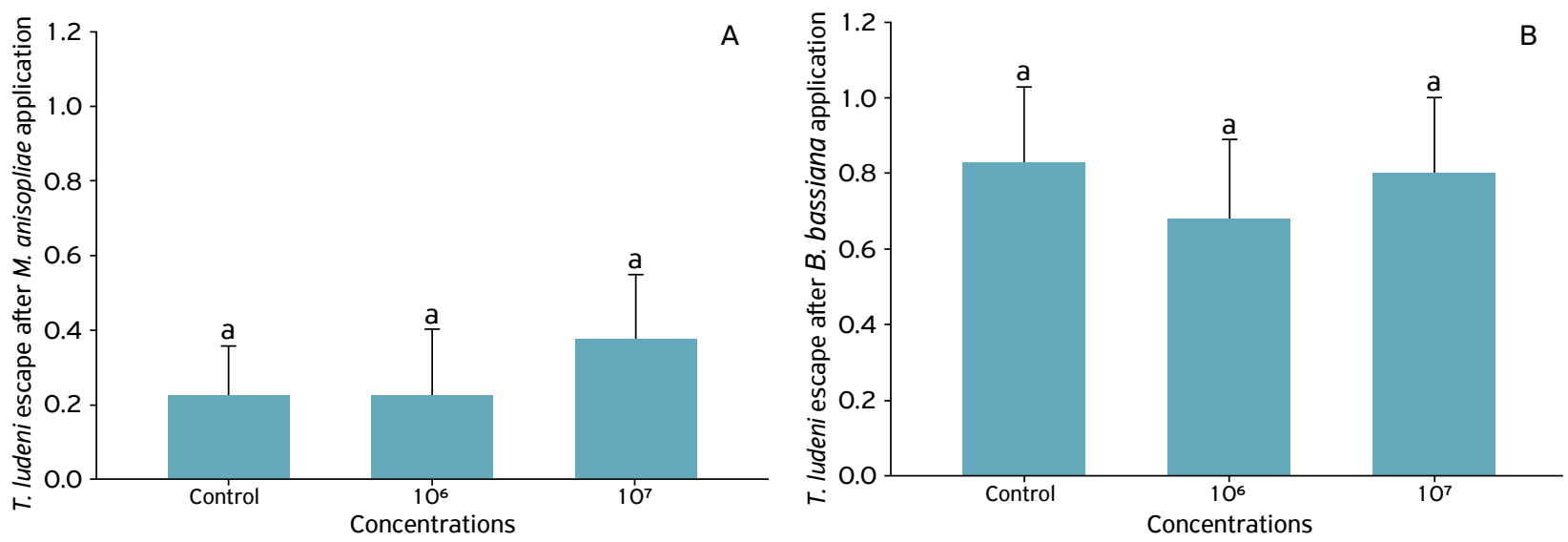

Figure 3. Effect of repellent of Tetranychus ludeni females after applying different concentrations of (A) Metharhizium anisopliae; and (B) Beauveria bassiana. Means were compared with the Tukey test, $\mathrm{p} \geq 0.05$. 


\section{CONCLUSIONS}

The $M$. anisopliae fungus has the potential to be used as a biological control agent, with a concentration of $10^{7} \mathrm{con} \cdot \mathrm{mL}^{-1}$, efficient for population control of the T. ludeni phytophagous mite. The $B$. bassiana fungus has the potential to suppress future generations of the mite by reducing the oviposition rate at both concentrations tested.

\section{ACKNOWLEDGEMENT}

We thank the Brazilian agencies Conselho Nacional de Desenvolvimento Científico e Tecnológico (CNPq), and Fundaçáo de Amparo à Pesquisa do Estado de Minas Gerais (FAPEMIG) for the scholarships and financial support granted. This study was partly financed by Coordenação de Aperfeiçoamento de Pessoal de Nível Superior - Brasil (CAPES), Finance Code 001.

| | | | | | | | | | | | | | | | | | | | | | | | | | | | | | | | | | | | | | | | | | | | | | | | | | | | | | | | | | | | | | | | | | | | | | | | | | | | | | | | | | | | | | | | | | | | | | | | | | | | | | | | | | | | | | | | | | | | | | | | | | | | | | | | | | | | | | | | | | | | | | | | | | | | | | | | | | | | | | | | | | | | | | | | | | | | | | | | | | | | | | | | | | | | | | | | | | | | | | | | | | | | | | | | | | | | | | | | | | | | REFERENCES

ALMEIDA, A.M.B.; BATISTA FILHO, A.; TAVARES, F.M.; LEITE, L.G.; JUNQUEIRA, L.K. Seleção de isolados de Beauveria bassiana para o controle de Cosmopolites sordidus (Germar, 1824) (Coleoptera: Curculionidae). Arquivos do Instituto Biológico, São Paulo, v.69, Supl., p.540-542. 2006. Available from: <http://www.biologico. sp.gov.br/uploads/docs/bio/suplementos/v68_supl/p540-542. pdf>. Access on: 9 Feb. 2017.

ANDRADE JÚNIOR, V.C.; VIANA, D.J.S.; PINTO, N.A.V.D.; RIBEIRO, K. G.; PEREIRA, R.C.; NEIVA, I.P.; AZEVEDO, A.M.; ANDRADE, P.C. DE R. Características produtivas e qualitativas de ramas e raízes de batata-doce. Horticultura Brasileira, Brasília, v.30, n.4, p.584-589, 2012. Available from: <http://www.scielo.br/pdf/ hb/v30n4/v30n4a04.pdf>. Access on: 15 Sep. 2017. http:// dx.doi.org/10.1590/SO102-05362012000400004

AZEVEDO, A.M.; ANDRADE JÚNIOR, V.C.; FERNANDES, J.S.C.; PEDROSA, C.E.; OLIVEIRA, C.M. Desempenho agronômico e parâmetros genéticos em genótipos de batata-doce. Horticultura Brasileira, Brasília, v.33, n.1, p.84-90, 2015. Available from: <http://www.scielo.br/pdf/hb/v33n1/01020536-hb-33-01-00084.pdf > . Access on: 8 Jan. 2017. http:// dx.doi.org/10.1590/S0102-053620150000100014

BARRETO, R.S.; MARQUES, E.J.; GONDIM JR.; M.G.C., DE OLIVEIRA, J.V. Selection of Beauveria bassiana (BALS.) VUILL. and Metarhizium anisopliae (METSCH.) Sorok for the control of the Mite Mononychellus tanajoa (BONDAR). Scientia Agricola, Piracicaba, v.61, n.6, p.659-664, 2004. Available from: <http:// www.scielo.br/pdf/sa/v61n6/a 15v61n6.pdf>. Access on: 6 Feb. 2017.

BUGEME, D.M.; KNAPP, M.; EKESI, S.; CHABI-OLAYE, A.; BOGA, H.I.; MANIANIA, N.K. Efficacy of Metarhizium anisopliae in controlling the two-spotted spider mite Tetranychus urticae on common bean in screenhouse and field experiments. Insect Science, Medford, v.22, n.1, p.121-128, 2015. Available from: <http://onlinelibrary.wiley.com/doi/10.1111/17447917.12111/epdf>. Access on: 5 Mar. 2017. https://doi. org/10.1111/1744-7917.12111

CASTRO, B.M.C.; SOARES, M.A.; ANDRADE JÚNIOR, V.C.; FADINI, M.A.M.; FERREIRA, J.A.M.; MORAES G.J. The predatory mite Phytoseiulus macropilis (Acari: Phytoseiidae) occurring on sweet potato (Ipomoea batatas) plants in Diamantina, Minas Gerais State, Brazil. Brazilian Journal of Biology, São Carlos, v.74, n.3, p.685-686, 2014. Available from: <http://www.scielo.br/pdf/ bjb/v74n3/15 19-6984-bjb-74-03-685.pdf>. Access on: 2 Jan. 2017. http://dx.doi.org/10.1590/bjb.2014.0078

COSTA, V.H.D.; SOARES, M.A.; RODRÍGUEZ, F.A.D.; ZANUNCIO, J.C.; SILVA, I.M.; VALICENTE, F.H. Nomuraea rileyi (Hypocreales: Clavicipitaceae) in Helicoverpa armigera (Lepidoptera: Noctuidae) Larvae in Brazil. Florida Entomologist, Lutz, v.98, n.2, p.796798, 2015. Available from: <http://www.bioone.org/doi/ pdf/10.1653/024.098.0263>. Access on: 2 Jan. 2017.

KAIMAL, S.G.; RAMANI, N. Feeding biology of Tetranychus ludeni Zacher (Acari: Tetranychidae) on velvet bean. Systematic and Applied Acarology, Auckland, v. 16, n.3, p.228-234, 2011 . Available from: <http://www.acarology.org/saas/saa/saa 16/2011-16-228234f.pdf > . Access on: 2 Jan. 2017.

KHEDERI, S.J.; DE LILLO, E.; KHANJANI, M.; GHOLAMI, M. Resistance of grapevine to the erineum strain of Colomerus vitis (Acari: Eriophyidae) in western Iran and its correlation with plant features. Experimental and Applied Acarology, Amsterdam, v.63, n. 1, p. 15-35, 2014. Available from: <https://link.springer.com/ content/pdf/10.1007\%2Fs 10493-014-9778-y.pdf>. Access on: 2 Jan. 2017. https://doi.org/10.1007/s10493-014-9778-y

KOUSIK, C.S.; SHEPARD, B.M.; HASSELL, R.; LEVI, A.; SIMMONS, M. Potential sources of resistance to broad mites (Polyphagotarsonemus latus) in watermelon germplasm. HortScience, Virgínia, v.42, n.7, p.1539-1544, 2007. Available from: <https://journals.ashs.org/ hortsci/view/journals/hortsci/42/7/article-p 1539.xml>. Access on: 4 Feb. 2017. https://doi.org/10.21273/HORTSCI.42.7.1539

KURTTI, T.J.; KEYHANI, N.O. Intracellular infection of tick cell lines by the entomopathogenic fungus Metarhizium anisopliae. Microbiology, London, v.154, n.6, p.1700-1709, 2008. Available from: <http://www.microbiologyresearch.org/docserver/fulltext/ micro/154/6/1700.pdf?expires $=1505500422 \&$ id=id\&accn ame $=$ quest $\&$ checksum $=9$ A8EC $7 F D 84383 D 948 B 8 C 8 C 15 B C$ 57CFOA>. Access on: 4 Feb. 2017. https://doi.org/10.1099/ mic.0.2008/016667-0

LI, Y.; LEI, Z.; WANG, H. Selection of Beauveria bassiana strains against Frankliniella occidentalis and their conidial production characteristics. Chinese Journal of Biological Control, Beijing, v.29, n.2, p.219-226, 2013. Available from: <http://caod. oriprobe.com/articles/32494267/Selection_of_Beauveria_ bassiana_Strains_against_Frankliniella_occident.htm $>$. Access on: 4 Feb. 2017. 
MASSAROTO, J.A.; MALUF, W.R.; GOMES, L. A.A.; GONÇALVES, R.J.S.; SILVA, V.F.; LASMAR, A. Avaliação de genótipos de batata-doce para produção de raízes e ramas para alimentação animal. Varia Scientia Agrárias, Cascavel, v.3, n.1, p.77-86, 2013. Available from: <http://e-revista.unioeste.br/index.php/ variascientiaagraria/article/download/5601/6176>. Access on: 9 Feb. 2017.

MEYLING, N.V.; LÜBECK, M.; BUCKLEY, E.P.; EILENBERG, J.; REHNER, S.A. Community composition, host range and genetic structure of the fungal entomopathogen Beauveria in adjoining agricultural and seminatural habitats. Molecular Ecology Resources, Medford, v.18, n.6, p.1282-1293, 2009. Available from: <http://onlinelibrary.wiley.com/doi/10.1111/j.1365294X.2009.04095.x/epdf>. Access on: 9 Feb. 2017. https:// doi.org/10.1111/j.1365-294X.2009.04095.x

MINEIRO, J.L.C.; MONTES, S.M.N.M.; RAGA, A. Primeiro registro de Tetranychus desertorum (Banks) (Acari: Tetranychidae) em batata-doce (Ipomoea batatas L.). Arquivos do Instituto Biológico, São Paulo, v.69, n.2, p.113-198, 2007. Available from: <http:// www.biologico.agricultura.sp.gov.br/uploads/docs/bio/v69_2/ p186.pdf>. Access on: 9 Feb. 2017.

MINISTÉRIO DA AGRICULTURA, PECUÁRIA E ABASTECIMENTO (MAPA). Sistema de agrotóxicos fitossanitários. Available from: <http://extranet.agricultura.gov.br/agrofit_cons/principal_ agrofit_cons>. Access on: 8 Feb. 2016.

MORO, L.B.; POLANCZK, R.A.; PRATISSOLI, D.; CARVALHO, J.R.; FRANCO, C.R. Potencial do uso de fungos acaropatogênicos no controle de Tetranychus urticae Koch (Acari: Tetranychidae) em mamoeiro: efeito de cultivares sobre a patogenicidade. Arquivos do Instituto Biológico, São Paulo, v.78, n.2, p.267-272, 2011. Available from: <http://revistas.bvs-vet.org.br/arqib/article/ viewFile/25325/26194>. Access on: 9 Feb. 2017.

RIBEIRO, A.E.L.; GONDIM, M.G.; CALDERAN, E.; DELALIBERA, I. Host range of Neozygites floridana isolates (Zygomycetes: Entomophthorales) to spider mites.Journal of Invertebrate Pathology, Amsterdam, v. 102, n.3, p. 196-202, 2009. Available from: <http://ac.els-cdn.com/SO022201109001797/1 s2.0-S0022201109001797-main.pdf?_tid=4b21 c8ce9b95-11 e7-8755-00000aacb35d\&acdnat = 1505645297 a8ab4ea062680aae30c3eOf 19 bca 1 b3d >. Access on: 9 Feb. 2017. https://doi.org/10.1016/j.jip.2009.08.012

ROSAS-ACEVEDO, J.L.; BOUCIAS, D.G.; LEZAMA, R., SIMS, K.; PESCADOR, A. Exudate from sporulating cultures of Hirsutella thompsonii inhibit oviposition by the two-spotted spider mite Tetranychus urticae.Experimental and Applied Acarology, Amsterdam, v.29, n.3-4, p.213-225, 2003. Available from: <https://link. springer.com/article/10.1023/A:1025801817004>. Access on: 9 Feb. 2017. https://doi.org/10.1023/A:1025801817004

ROSSONI, C.; KASSAB, S.O.; LOUREIRO, E.S.; PEREIRA, F.F.; COSTA, D.P.; BARBOSA, R.H.; ZANUNCIO, J.C. Metarhizium anisopliae and Beauveria bassiana (Hypocreales: Clavicipitaceae) are Compatible with Cotesia flavipes (Hymenoptera: Braconidae). Florida Entomologist, Lutz, v.97, n., p. 1794-1804, 2014. Available from: <http://journals.fcla.edu/flaent/article/view/83894/80784>. Access on: 9 Feb. 2017.
SANJAYA, Y.; OCAMPO, V.R.; CAOILI, B.L. Role of new novel entomopathogenic fungi Paecilomyces lilacinus to mortality and infection process of Tetrancyhus kanzawai (Kishida) (Tetranychidae: Acarina). International Journal of Biosciences, Dhaka, v.7, n.3, p.16-23, 2015. Available from: <https://www.researchgate.net/ publication/299827711_Role_of_new_novel_entomopathogenic_ fungi_Paecilomyces_lilacinus_to_moratality_and_infection_process_ of_Tetranychus_kanzawai_Kishida_TetranychidaeAcarina $>$. Access on: 9 Feb. 2017. http://dx.doi.org/10.12692/ijb/7.3.16-23

SANTOS, J.F.; BRITO, C.H.; SANTOS, M.C.C.A. Avaliação da produção de batata-doce em função de níveis de adubação orgânica. Acta Scientiarum Agronomy, Maringá, v.32, n.4, p.663-666, 2010. Available from: <http://periodicos.uem.br/ojs/index.php/ ActaSciAgron/article/view/4150/4150>. Access on: 9 Feb. 2017. http://dx.doi.org/10.4025/actasciagron.v32i4.4150

SEYED-TALEBI, F.S.; KHERADMAND, K.; TALAEI-HASSANLOUI, R.; TALEBI-JAHROMI, K. Sublethal effects of Beauveria bassiana on life table parameters of two-spotted spider mite, Tetranychus urticae (Acari: Tetranychidae). Biocontrol Science and Technology, Londres, v.22, n.3, p.293-303, 2012. Available from: <https:// www.researchgate.net/publication/236165699_Sublethal_ effects_of_Beauveria_bassiana_on_life_table_parameters_of_twospotted_spider_mite_Tetranychus_urticae_Acari_Tetranychidae>. Access on: 9 Feb. 2017. http://dx.doi.org/10.1080/095831 57.2012 .655709

SHI, W.B.; FENG, M.G. Effect of fungal infection on reproductive potential and survival time of Tetranychus urticae (Acari: Tetranychidae). Experimental and Applied Acarology, Amsterdam, v.48, n.3, p.229-237, 2009. Available from: $<$ https://www.researchgate.net/publication/23801467_ Effect_of_fungal_infection_on_reproductive_potential_and_survival_ time_of_Tetranychus_urticae_Acari_Tetranychidae>.Access on: 9 Feb. 2017. http://dx.doi.org/10.1007/s10493-009-9238-2

SILVA, A.C.B.; TEODORO, A.; OLIVEIRA, E.E.; RÊGO, A.S.; SILVA, R.R. Toxicity of neem oil to the cassava green mite Mononychellus tanajoa (Bondar) (Acari: Tetranychidae). Chilean Journal of Agricultural Research, Chillán, v.73, n.3, p.315-319, 2013. Available from: <http://www.scielo.cl/pdf/chiljar/v73n3/at 16. pdf>. Access on: 9 Feb. 2017. https://doi.org/10.4067/ SO718-58392013000300016

SOARES, M.A.; CASTRO, B.M.C.; ANDRADE-JÚNIOR, V.C.; ASSISJÚNIOR, S.L.; PIRES, E.M. Attack of two new spider mites on sweet potato (Ipomoea batatas) in Diamantina, Minas Gerais State, Brazil. Brazilian Journal of Biology, São Carlos, v.72, n.4, p.971, 2012. Available from: <http://www.scielo.br/pdf/bjb/ v72n4/29.pdf>. Access on: 9 Feb. 2017.

SONG, H.Y.; LEE, S.Y.; CHOI, S.J.; KIM, K.M.; KIM, J.S.; HAN, G.J.; MOON, T.W. Digestibility and physicochemical properties of granular sweet potato starch as affected by annealing. Food Science and Biotechnology, Gangnam-gu, v.23, n.1, p.23-31, 2014. Available from: <https://link.springer.com/article/10. 1007\%2Fs 10068-014-0004-9>. Access on: 9 Feb. 2017. https://doi.org/10.1007/s10068-014-0004-9

TAMAI, M.A.; ALVES, S.B.; ALMEIDA, J.E.M.; FAION, M. Avaliação de fungos acaropatogênicos para o controle de Tetranychus urticae Koch (Acari: Tetranychidae). Arquivos do Instituto Biológico, São 
Paulo, v.69, n.3, p.77-84. 2002. Available from: <http://www. biologico.sp.gov.br/uploads/docs/arq/V69_3/Tamai2.pdf $>$. Access on: 9 Feb. 2017.

TORRADO-LEÓN, E.; MONTOYA-LERMA, J.; VALENCIA-PIZO, E. Sublethal effects of Beauveria bassiana (Balsamo) Vuillemin (Deuteromycotina: Hyphomycetes) on the whitefly Bemisia tabaci (Gennadius) (Hemiptera: Aleyrodidae) under laboratory conditions. Mycopathologia, Berkeley, v.162, n.6, p.411-419, 2006. Available from: <https://link.springer.com/article/10.1007/ s1 1046-006-0077-y>. Access on: 9 Feb. 2017. https://doi. org/10.1007/s1 1046-006-0077-y

ULLAH, M.S.; LIM, U.T. Laboratory bioassay of Beauveria bassiana against Tetranychus urticae (Acari: Tetranychidae) on leaf discs and potted bean plants. Experimental and Applied Acarology, Amsterdam, v.65, n.3, p.307-318, 2015. Available from: <https://link.springer. com/article/10.1007/s10493-014-9871-2>. Access on: 9 Feb. 2017. https://doi.org/10.1007/s10493-014-9871-2

WANG, D.J.; ZANG, L.S.; ZHANG, Y.; WANG, H.H.; LEI, Z. Sublethal effects of Beauveria bassiana Balsamo on life table parameters of subsequent generations of Bemisia tabaci Gennadius. Scientia Agricultura Sinica, Pequim, v.47, n.18, p.3588-3595,
2014. Available from: <https://www.tib.eu/de/suchen/id/ BLSE\%3ARN364364633/Sublethal-Effects-of-Beauveriabassiana-Balsamo/>. Access on: 9 Feb. 2017.

WEKESA, V.W.; MANIANIA, N.K.; KNAPP, M.; BOGA, H.I. Pathogenicity of Beauveria bassiana and Metarhizium anisopliae to the tobacco spider mite Tetranychus evansi. Experimental and Applied Acarology, Amsterdam, v.36, n.1-2, p.41-50, 2006. Available from: <https://link.springer.com/article/10.1007/ s10493-005-0508-3>. Access on: 9 Feb. 2017. https://doi. org/10.1007/s 10493-005-0508-3

ZHANG, T.; REITZ, S.R.; WANG, H.; LEI, Z. Sublethal Effects of Beauveria bassiana (Ascomycota: Hypocreales) on life table parameters of Frankliniella occidentalis (Thysanoptera: Thripidae). Journal of Economic Entomology, Oxford, v.108, n., p.975-985, 2015. Available from: <https://www.researchgate.net/profile/ Stuart_Reitz/publication/276131715_Sublethal_Effects_of_ Beauveria_bassiana_Ascomycota_Hypocreales_on_Life_Table_ Parameters_of_Frankliniella_occidentalis_Thysanoptera_Thripidae/ links/5551046a08ae739bdb92048c/Sublethal-Effects-of-Beauveriabassiana-Ascomycota-Hypocreales-on-Life-Table-Parameters-ofFrankliniella-occidentalis-Thysanoptera-Thripidae.pdf>. Access on: 9 Feb. 2017. 